Original Paper http://ajol.info/index.php/ijbcs http://indexmedicus.afro.who.int

\title{
Stabilization by co-composting dry drain sludge with fermentescible fractions of household garbage from the city of Sokodé (Togo)
}

\author{
Nitale M'Balikine KROU ${ }^{1 *}$, Gnon BABA ${ }^{1}$, Jaime MARTÍN-PASCUAL ${ }^{2}$ and \\ Montserrat ZAMORANO TORO ${ }^{2}$
}
${ }^{1}$ Laboratory of Sanitation Water Sciences and Environment (LASEE); Faculty of Science and Technology, Department of Chemistry, University of Kara, BP. 404 Kara, Togo.
${ }^{2}$ Laboratory of Civil Engineering, Faculty of Sciences, Department of Chemical Engineering, University of Granada, Spain.
*Corresponding author; E-mail: krounitale@gmail.com; Tel: (00228)911910915.

\begin{abstract}
The management of fecal sludge is a recurrent problem for the actors in charge of the urban environment of Sokodé. Often, the sludge emptied is poured on empty spaces or used, without treatment, on urban and suburban agricultural land and for market gardening; in fact, a survey of market gardeners in the city of Sokodé found that around $40 \%$ of them directly use untreated dried sludge to amend their production areas. Consequently, bacteria and worm eggs can adhere to vegetable products and infect consumers. In view of these potential risks, the objective of this work was then to stabilize the organic matter of dried sludge with a view to their hygienic use for the agricultural amendment. In this research it has been developed compost obtained from fermentable fractions of household waste and compost obtained from the fermentable fractions of household waste with sludge (co-composting). Results have shown that both types of compost have a high content of nutrients, which is an advantage for use in the agriculture. Therefore, the assessment of stability and maturity parameters shows that co-composted sludge produces mature compost and can improve soil fertility without biological risk.
\end{abstract}

(C) 2019 International Formulae Group. All rights reserved

Keywords: Bacteria, worm eggs, sludge, organic materials, market gardening.

\section{INTRODUCTION}

The accelerated growth of the population in the developing countries generates an increase of the food demand (FAO, 2017). To satisfy this demand, agricultural intensification appears as an unavoidable option which is putting pressure on the ecosystem and in turn leading to reduced soil fertility, so farmers apply nutrients in the form of chemical fertilizers and animal manure to provide the nitrogen and phosphorus that crops need to grow. Chemical fertilizers increase crops costs; besides, the excessive use of fertilizers produces negative environmental impact because not fully utilized nitrogen and phosphorus can be lost from the farm fields producing soil salinity, heavy metal accumulation, water eutrophication and accumulation of nitrate, to consider in terms of air pollution in the air of gases containing nitrogen and sulfur, giving and can lead to 
problems such as the greenhouse effect (Savci, 2012).

An alternative to chemical fertilizers is the use of drained sludge to reduce pathogens, but also to eliminate odor and reduce organic matters, preventing or inhibiting future decomposition (Ouedraogo, 2016). Stabilized drained sludge results on organic amendment properties, but also on a source of nutrients as nitrogen, phosphorus and potassium which give them organic fertilizer properties (Ouedraogo, 2016), so they can therefore be a substitute or supplement to synthetic mineral fertilizers, thereby closing carbon and nutrient cycles (Savci, 2012).

In developing countries, urban areas are estimated to have higher sanitation coverage than rural areas (Carlton et al., 2012), but statistics had often not come out clearly to show the severity and complexity of sanitation challenges affecting towns and the urban poor (Letah et al., 2019). Besides not landfilling of this waste reduces environmental impact (Ouedraogo, 2016), in the developing countries, in terms of sanitation, drained sludge is most often discharged near watercourses, empty spaces or reused without treatment on agricultural land. Thus, the establishment of a fecal sludge management plan is necessary for the adequate protection of the environment and public health (Douanla et al., 2019). But usually, an agreement has been reached between some farmers and mechanical dumpers and the sludge is being dumped in their fields without any sanitation. For example, in Sokodé (Togo) a survey of market gardeners in the city revealed that because of poor soils, around $40 \%$ of them directly use untreated dried fecal sludge to amend their production areas (PEAT2, 2018). Since the sludge is not treated, bacteria and worm eggs can adhere to plants (market garden and agricultural products) and infect people who consume them raw or poorly washed (Ouedraogo, 2016). Human excreta are used to support food production in many countries all around the world. However, reuse of untreated feces for agricultural purposes can bare a great health risk, because a great number of pathogens can be found in human excreta (Gallizzi, 2003). It has been shown that fecal sludge in Ouagadougou after drying for three months, still contains an average of 615 helminth eggs, 25 eggs / g and 932 protozoan cysts, 37 cysts / $\mathrm{g}$ of dried mud (Ouedraogo, 2016). Thus, drying alone does not eliminate all pathogens. In consequence it is necessary composting sludge to improve quality but several studies on composting of sludge have shown that a sufficiently high temperature for the destruction of pathogens is difficult to achieve because temperatures normally increase by 10 to $15{ }^{\circ} \mathrm{C}$ above ambient (Bjorklund, 2002). Thus the use of sludge only for market gardening and agriculture is a danger for consumers. However, the co-composting with the fermentable fractions of the solid waste with this dewatered sludge could produce hygienic composts because during the co-composting process, the sludge is disinfected because the pathogens present in the sludge are destroyed or inactivated during the thermophilic phase (temperature between 40 and $70{ }^{\circ} \mathrm{C}$ ) (Gallizzi, 2003). In addition, this fecal sludge will integrate into the production cycle not as waste, but as a source that can contribute to improving the living conditions of the population by increasing agricultural production. Thus, the objective of this work was to stabilize the organic matter of the dried sludge by co-composting the sludge with the fermentable fractions of the household waste for their hygienic use for the agricultural amendment.

The pretreatment of these sludges by co-composting, in combination with the fermentable fractions of the solid waste of the city of Sokodé, could be an added value for these market gardeners and farmers while limiting the financial efforts of the poorest to buy chemical fertilizer.

\section{MATERIALS AND METHODS Materials}

Organic waste used in this research came from Sokodé, capital of the Central Region and the Prefecture of Tchaoudjo, located between $8^{\circ} 57$ 'and $9^{\circ} 03^{\prime}$ of Latitude 
North and $1^{\circ} 05$ 'and $1^{\circ} 11^{\prime}$ of Longitude East, $346 \mathrm{~km}$ north of Lomé, it has long been the regional capital of the northern zone and especially the second center of settlement of the country. With a population estimated at 111258 inhabitants, Sokodé enjoys a tropical climate of transition between Guinean (wet) and Sudano-Sahelian (dry).

Two fractions have been used for cocomposting process: organic matter from municipal solid waste which are a mixture of household waste, hotels, markets, restaurants and training centers; and dried sludge from dry pits, septic tanks and public septic tanks have been used to study co-composting process. In the co-composting swath, dried sludge accounts for $1 / 3$ and fermentable fractions of solid waste $2 / 3$ (photo1) (Remy, 2007; ADEME, 2015). These proportions make it possible to obtain an essential lacuna mixture to the air circulation (Remy, 2007). Standard compost here is compost made only from fermentable fractions of household waste. It was done in order to compare decomposition processes with co-compost.

Turnaround times correspond exactly to a fixed duration (every two weeks). The windrows were returned two (02) times during the fermentation phase in the (2nd and 5th) week and two (02) times (7th and 9th week) during the ripening phase to promote their homogenization (Koledzi et al., 2011). The co-composting period was set at three months and maturation was done under the shed (covered area). The resulting compost was screened and then stored.

\section{Methods \\ Agronomic characteristics of dried sludge and FFOM}

Dryness, organic matter, total organic carbon content, total phosphorus content $\left(\mathrm{P}_{2} \mathrm{O}_{5}\right)$, magnesium and potassium content have been determined to characterize dried sludge and FFOM used in this research. Dryness indicates the water content of the sludge, and it was obtained after drying at 150 ${ }^{\circ} \mathrm{C}$ for 2 hours. In the fermentescible fractions of household waste (FFOM), dryness has been obtained after drying at $105{ }^{\circ} \mathrm{C}$ for 2 hours.
The organic matter content was determined in the dried sludge and in the fermentable fractions of the solid waste by the loss-to-fire method. The total organic carbon content and total phosphorus content $\left(\mathrm{P}_{2} \mathrm{O}_{5}\right)$ were determined after oxidation and Spectrometric assay, respectively. Total Kjeldhal Nitrogen (NTK) was obtained by mineralization of the samples in acidic medium and in the presence of catalyst. Finally, the magnesium concentration and the potassium content in the samples were determined by titration with Ethyl tetra acetic diamine (EDTA) after aqua regia extraction and by Atomic Absorption Spectrometry, respectively.

\section{Co-composting process control}

Humidity, temperature, $\mathrm{pH}$, organic matter and the $\mathrm{C} / \mathrm{N}$ ratio have been monitored to control co-composting process. They were evaluated every two weeks throughout the process.

The moisture content is determined by drying at $105{ }^{\circ} \mathrm{C}$ (Yobouet et al., 2010), the temperature by electronic thermometer, the $\mathrm{pH}$ by an aqueous suspension according to standard method AFNOR NF ISO 10-390 (Belyaeva et al., 2009) and the rate of organic matter by calcination at $550{ }^{\circ} \mathrm{C}$ (Unmar et al. 2008).

Total phosphorus was determined by colorimetry using ammonium molybdate and ascorbic acid (Bustamante et al., 2008).

\section{Compost quality}

The quality of the compost was evaluated by the total nitrogen content (TNK), the $\mathrm{C} / \mathrm{N}$ ratio, total phosphorus. In addition, the application of the respirometric test, selfheating tests (TAE), the determination of the index germination (GI), exchangeable cations $(\mathrm{Ca}, \mathrm{Mg}, \mathrm{Na}$ and $\mathrm{K}$ ) and the cation exchange capacity (CEC) and then the heavy metal content were used to evaluate the maturity and stability of the composts produced.

Kjeldahl nitrogen (NTK) is determined by the Kjeldahl method (Barrena et al., 2010) as described by AOAC (Association of Official Analytical Chemists). Total phosphorus was determined by colorimetry using ammonium molybdate and ascorbic acid (Bustamante et al., 2008). 
Stability and maturity were evaluated by performing the AT4 respirometric test at four days, determining the germination index (GI) and the cation exchange capacity (CEC). To do that, the composts were placed under specific conditions of temperature, humidity and thermostatically controlled chamber at 20 $\pm 1{ }^{\circ} \mathrm{C}$ inside a Dewar vase, and the temperature has been monitored for 10 days, so the maturity index is a function of the highest temperature reached during the test.

Respiratory test is based on the measurement of the Biological Oxygen Demand (BOD) obtained will be facilitated by the use of Oxitop ${ }^{\circledR}$ WTW (Barrena et al., 2010; Unmar and Mohee, 2008).

Phytotoxicity of composts has been determined by the effect of aqueous extracts of compost on the germination of corn seeds (Zea mays), cowpea (unguiculata of Virgna)) considered staple crops in Togo and cress (Lepidium sativum L) (Miyuki et al., 2005). The GI was calculated by the formula of (Koledzi et al., 2019):

$G I=\frac{N m g g \times L r}{N m g g t \times L r t}$ Eq.1 where
Nmgg: Number of sprouts; Lr: average length of the root;

Nmggt: Number of seeds sprouted from witness; Lrt: average length of the control root

Self-heating tests (TAE), developed in Europe, is recommended by the German standardization body (Bundes Gütegemeinschaft Kompost BGK) (F.C.Q.A.O, 1994). The maturity index is a function of the highest temperature reached during the test. The latter is qualified as: ripe for a degree of ripening of $\mathrm{V}$ (temperature $<30$ ${ }^{\circ} \mathrm{C}$ ) or a degree of IV (temperature $<40{ }^{\circ} \mathrm{C}$ ); fresh compost for degree III

Cation Exchange Capacity (CEC) is the maximum total amount of cations compost can trap at a given $\mathrm{pH}$. The exchangeable Cations $(\mathrm{Ca}, \mathrm{Mg}, \mathrm{K}$ and $\mathrm{Na}$ ) and the content of metallic trace elements $(\mathrm{Zn}, \mathrm{Cu}, \mathrm{Ni}, \mathrm{Cd}$, $\mathrm{Pb})$ were determined by Atomic Absorption Spectrophotometer (Koledzi et al., 2019). For a compost to be used as an organic fertilizer, its metallic trace element content must respect certain ecological standards. Since Togo does not have a standard, international standars have been used (Table 1).

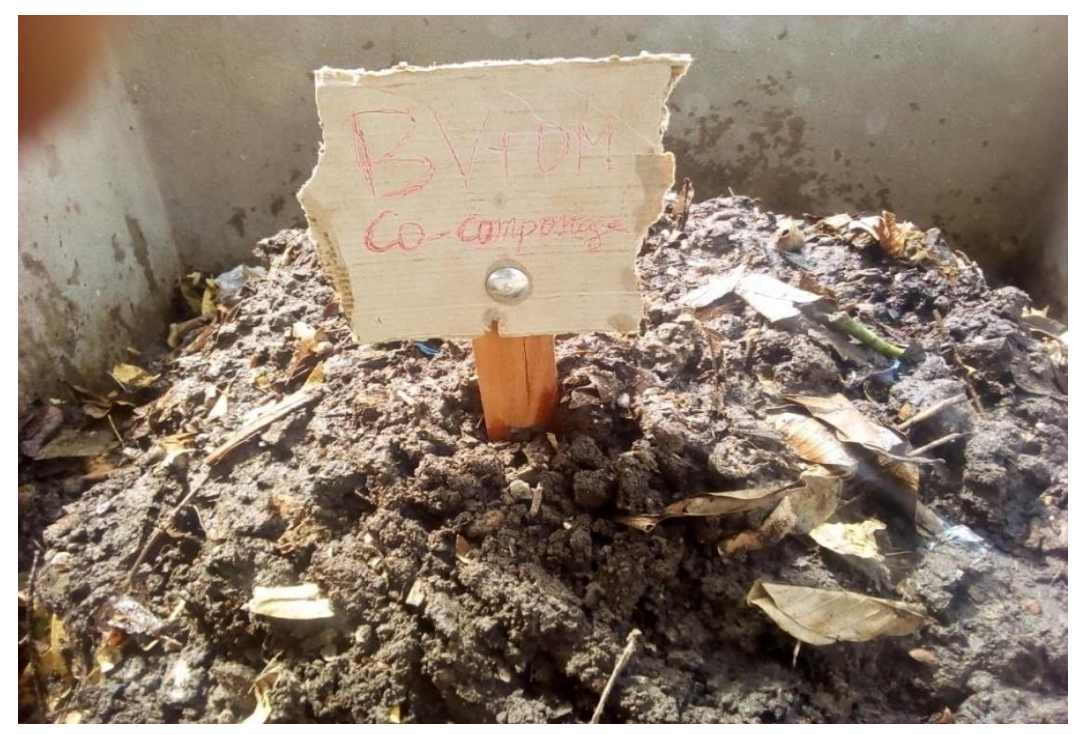

Photo 1: Co-composting dry fecal sludge and organic solid waste. 
Table1: Standard NFU 44-051 of metallic trace element in compost at the end of the process.

\begin{tabular}{lccccc}
\hline Items analyzed & $\begin{array}{c}\mathrm{Cu} \\
(\mathrm{mg} / \mathrm{kg})\end{array}$ & $\begin{array}{c}\mathrm{Zn} \\
(\mathrm{mg} / \mathrm{kg})\end{array}$ & $\mathrm{Ni}(\mathrm{mg} / \mathrm{kg})$ & $\begin{array}{c}\mathrm{Cd} \\
(\mathbf{m g} / \mathbf{k g})\end{array}$ & $\mathrm{Pb}(\mathbf{m g} / \mathbf{k g})$ \\
\hline NFU 44-051 & 300 & 600 & 60 & 3 & 180 \\
\hline
\end{tabular}

\section{RESULTS}

The results are discussed in a first part in relation to the characterization of organic sources used, followed by follow-up of the cocomposting process and in a second part in relation to the quality of the compost obtained. The results of co-composting are compared with those of standard composting in order to highlight the interest of this process.

\section{Agronomic characteristics of dried sludge and FFOM}

Given the absence of national standards on the nutrients of recoverable biosolids, the AFNOR NFU 44-095 standards applicable to composts were used to exploit our results of the agronomic parameters of the substrates (dried sludge and fermentable fractions of solid waste). The standard NFU 44-095 is specific for the placing on the market of composts containing sludge from water treatment. The standard NFU 44-051 is specific for the placing on the market of all other types of composts.

Table 2 shows dried sludge and FFOM characterization, including a comparative analysis of the fulfilment of agronomic parameters with the requirements of NFU 44095 and of NFU 44-051.

In the case of dried sludge, dryness is $80.20 \%$. They also contain $54.72 \%$ organic matter relative to the dry matter. Indeed, the nutrient content gives $0.31 \%$ nitrogen, $1.30 \%$ phosphorus and $0.19 \%$ potassium and $0.48 \%$ $\mathrm{MgO}$ for the dried sludge. These grades are lower than those required by NFU 44-095.

The fermentable fraction of solid household waste contain $60.2 \%$ organic matter relative to the dry matter. The nutrient content gives $0.74 \%$ for nitrogen, $0.18 \%$ for phosphorus and $0.14 \%$ for potassium. Finally, the $\mathrm{C} / \mathrm{N}$ ratios were $21 \%$ and $15.3 \%$ for dried sludge and FFOM, respectively.

\section{Control co-composting process}

The moisture content reached $62 \%$ in the standard compost pile and $65 \%$ in the cocompost pile. The moisture content was maintained between $35-62 \%$ for standard compost and 38-65\% for co-compost during the process (Figure 1). The moisture content at the end of the process is $35 \%$ for the standard compost and $43 \%$ for co-compost.

The daily temperature recorded during the co-composting process showed that, after four days, the temperature in the windrows reached $65{ }^{\circ} \mathrm{C}$ for co-compost and $70{ }^{\circ} \mathrm{C}$ for standard compost. These temperatures undergo an increase after each turn before decreasing. Temperatures varied between 45 $65{ }^{\circ} \mathrm{C}$ for co-compost and between $38-70{ }^{\circ} \mathrm{C}$ for standard compost in the fermentation phase and between $29-45^{\circ} \mathrm{C}$ and then between $30-36{ }^{\circ} \mathrm{C}$ in the ripening phase (respectively for co-compost and for standard compost).

By correlating the evolution of $\mathrm{pH}$ with organic matter, there are contrary variations. The $\mathrm{pH}$ increases while the organic matter content decreases (the organic matter content decreases more quickly in the pile of cocompost than in the standard compost). $\mathrm{pH}$ values remained between 6 and $8 \pm 0.01$ for the standard compost and between 6.5 and $8 \pm$ 0.01 for the co-compost in the fermentation phase. At the end of the process, the $\mathrm{pH}$ is 8.3 \pm 0.01 for standard compost and $8.1 \pm 0.01$ for co-compost. The evolution of organic matter during the process shows that initially the rate of organic matter is high in compost piles. This rate then undergoes a gradual decrease over time from the fifteenth day to a minimum 
value of about $36 \%$ for standard compost and $45 \%$ for co-compost.

The ratio $\mathrm{C} / \mathrm{N}$ decreases during composting (Table 3 ).

\section{Compost quality}

Compost quality has been analyzed in terms of nutrients content and the study of the maturity and stability of the compost.

\section{Content of nutrients}

$\%$ of $\mathrm{MO}, \%$ Ntotal, $\mathrm{C} / \mathrm{N}$ ratio, $\% \mathrm{P}_{2} \mathrm{O}_{5}$, $\% \mathrm{~K}_{2} \mathrm{O}$ and $\% \mathrm{MgO}$ have been analyzed to determine the quality of compost producen. Table 4 summarizes values obtained for both compost and co-compost produced.

Concerning nitrogenous matter content, at the end of process the results show $0.92 \%$ for the standard compost and $1.1 \%$ for the co-compost.

The quality of the compost at the end of the process could be also evaluated by its $\mathrm{C} / \mathrm{N}$ ratio. The results obtained show that the $\mathrm{C} / \mathrm{N}$ ratios presented are average but close to the value recommended by the standard NFU 44 - 051 which is 13 for mature compost. The
$\mathrm{C} / \mathrm{N}$ ratios of the two types of compost are comparable.

For the total phosphorus, the result show that the content is higher in co-compost (2.2\%) compared to that of standard compost $(1.8 \%)$.

In the case of the potassium, the content are $1.62 \%$ for standard compost and $1.54 \%$ for co-compost.

Finally, both types of compounds also have a high content of other nutrients such as $\mathrm{Na}_{2} \mathrm{O}, \mathrm{MgO}$, and $\mathrm{CaO}$ (Table 4).

\section{Maturity and stability of the compost}

Table 5 shows a practically constant consumption for the fourth day (for a degree of maturation of IV (temperature $<40{ }^{\circ} \mathrm{C}$ )) for both types of composts.

Values of GI in Table 5 shows that the composts produced have a germination index greater than $50 \%$. Finally, higher cation exchange capacity value is than $60 \mathrm{meq} /$ $100 \mathrm{~g}$ for both comports.

\section{Metallic trace element content}

The contents of metallic trace element are reported in Table 6.

Table 2: Agronomic characteristics of dried sludge and FFOM.

\begin{tabular}{|c|c|c|c|c|c|c|c|c|}
\hline Parameters & $\begin{array}{l}\text { Dryness } \\
(\%)\end{array}$ & $\% \mathrm{MO}$ & $\% \mathrm{COT}$ & $\%$ Ntotal & $\mathrm{C} / \mathrm{N}$ & $\% \mathrm{P}_{2} \mathrm{O}_{5}$ & $\% \mathrm{~K}_{2} \mathrm{O}$ & $\% \mathrm{MgO}$ \\
\hline $\begin{array}{l}\text { Dried } \\
\text { sludge }\end{array}$ & 80.20 & 54.72 & 6.51 & 0.31 & 21 & 1.30 & 0.19 & 0.48 \\
\hline FFOM & 39.2 & 60.2 & 11.35 & 0.74 & 15.3 & 0.18 & 0.14 & 0.12 \\
\hline NFU44-095 & $>50 \%$ & $>30 \%$ & - & $<3 \%$ & $\leq 25$ & $<3 \%$ & $<3 \%$ & - \\
\hline NFU44-051 & - & $>30 \%$ & - & $<3 \%$ & 13 & $<3 \%$ & $<3 \%$ & - \\
\hline
\end{tabular}

Table 3: C/N ratio during the process.

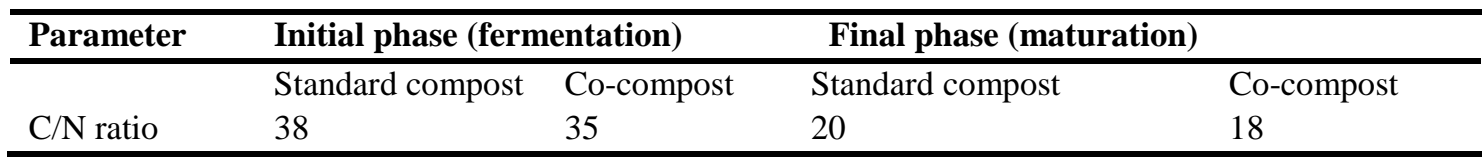


Table 4: Content of nutrients.

\begin{tabular}{lll}
\hline Items analyzed & Standard compost & Co-compost \\
\hline$\% \mathrm{MO}$ & 36 & 45 \\
$\% \mathrm{~N}$ Total & 0.92 & 1.1 \\
$\% \mathrm{C}$ & 11.8 & 14 \\
$\mathrm{C} / \mathrm{N}$ ratio & 12.83 & 12.72 \\
$\mathrm{P}_{2} \mathrm{O}_{5}(\%)$ & 1.8 & 2.2 \\
$\mathrm{~K}_{2} \mathrm{O}(\%)$ & 1.62 & 1.54 \\
$\mathrm{Na} 2 \mathrm{O}(\%)$ & 0.8 & 0.67 \\
$\mathrm{MgO}(\%)$ & 0.42 & 0.56 \\
$\mathrm{CaO}(\%)$ & 2.6 & 3.7 \\
$\mathrm{pH}$ & 8.3 & 8 \\
\hline
\end{tabular}

Table 5: Measurements of AT4, GI composts produced and Cation exchange capacity.

\begin{tabular}{lll}
\hline Items analyzed & Standard compost & Co-compost \\
\hline Self-heating capacity (AT4) & Degree IV (temperature $\left.<40{ }^{\circ} \mathrm{c}\right)$ \\
Germination index (IG) (\%) & 65 & 75 \\
Cation Exchange Capacity (CEC) (mg eq / 100g) & 64 & 68 \\
\hline
\end{tabular}

Table 6: Content of compost in Metallic trace element compared to standards NFU 44-051.

\begin{tabular}{llll}
\hline Items analyzed & Standard compost & Co-compost & NFU 44-051 \\
\hline $\mathrm{Cu}(\mathrm{mg} / \mathrm{kg})$ & 23 & 17 & 300 \\
$\mathrm{Zn}(\mathrm{mg} / \mathrm{kg})$ & 161 & 222 & 600 \\
$\mathrm{Ni}(\mathrm{mg} / \mathrm{kg})$ & 6 & 9 & 60 \\
$\mathrm{Cd}(\mathrm{mg} / \mathrm{kg})$ & 1 & 2 & 3 \\
$\mathrm{~Pb}(\mathrm{mg} / \mathrm{kg})$ & 17 & 20 & 180 \\
\hline
\end{tabular}

\section{DISCUSSION}

\section{Agronomic characteristics of dried sludge and FFOM}

Concerning the dryness value of dried sludge is greater than $50 \%$ required by the standard. This sludge is well dehydrated and can easily be transported to fields or compost sites. The content of organic matter meets the requirements of NFU 44-095, according to which the organic matter must be greater than $30 \%$ relative to the dry matter. The nutriments content are lower than those required by NFU 44-095.
For the fermentable fraction of solid household waste the content of organic matter meets the requirements of NFU 44-095 and of NFU44-051. The low content compared to that of fermentable fractions of solid wastes is due to the fact that most of the organic matter of raw sludge is lost through mineralization in the sanitation works (Ouédraogo, 2016).

The analyzes on the dried sludge show an organic matter in advanced state of decomposition compared to that of the fermentable fractions of the solid waste and whose nutritive elements would be more or 
less easily available for the plants (Ouedraogo, 2016).

The nutriments that found in the fermentable fractions of solid wastes are the main required for crop production. The values of $\mathrm{C} / \mathrm{N}$ ratio that found in dried sludge and in FFOM are lower than $25 \%$, limit stablished in guidliness considered. This ratio measures the relative proportions of carbon and nitrogen, nutrients essential for the life of microorganisms. Low values of dehydrated sludge and FFOM show that they cannot be used alone for compost at the risk of witnessing the putrefaction of the material accompanied by release of foul odors hence the need for co-composting with the biodegradable fractions of solid wastes for an improvement of the $\mathrm{C} / \mathrm{N}$ ratio. The contribution of fermentable fractions of solid waste is therefore a potentially important enrichment in nutrients. A compostable waste must have a $\mathrm{C} / \mathrm{N}$ ratio close to 15 in order to observe a sufficiently rapid degradation of the biodegradable organic matter (Koledzi et al., 2011). Thus, the fermentable fractions of the solid waste of the city of Sokodé, are of interest from the point of view of compostability, a C / $\mathrm{N}$ ratio is 15.3 .

In terms of normative references, it is possible conclude that the contents of the major fertilizers of dried sludge and fermentable fractions of solid wastes meet the quality requirements of NFU 44-095. Thus, this garbage can be used to produce compost as an organic amendment to reduce the excessive use of chemical fertilizers.

It can be concluded from thes characteristics that these substrates can be directly used for soil amendment. But it has been shown that drying alone does not eliminate all pathogens. Thus the use of sludge only for market gardening and agriculture is a danger for consumers. In addidion, the organic matter of both of dried sludge and FFOM is not stabilized hence the need for composting before use as soil amendment.

\section{Control co-composting process}

The results of the four parameters monitored during the composting and cocomposting (Photo 2) process such as the moisture content, the hydrogen potential, the organic matter content and the temperature are shown in Figures 1, 2, 3 and 4.

The rate of the moisture content decreased in both types of compost during the process. The small variation observed are due to the watering during the reverals. The moisture content is medium and sufficient for degradation of the organic matter, the optimum being between $40 \%$ and $60 \%$. The moisture content at the end of the process is in the range indicated in the literature which is between $35-45 \%$ for a mature compost (Koledzi, 2011).

The temperature decreases during the co-composting process to stabilize after three months. The values obtained during the cocomposting process are comparable to those found in the literature. Indeed, during a process of co-composting temperature between 40 and $70{ }^{\circ} \mathrm{C}$ ) (Gallizzi, 2003). For standard compost, the temperature range during the process is a normal process (Koledzi et al., 2011); in fact, the maximum temperature reached in the fermentation phase is sufficient to destroy certain pathogens and reduce the risk of contamination of vegetable products. Thus, the co-composting has the advantage of increasing the temperature that can destroy some pathogenic germs.

The values of $\mathrm{pH}$ are similar to those found by Koledzi (2011) which are between 5-8 for the initial phase and between 7-8.5 for the mature compost. The slightly acidic $\mathrm{pH}$ at the beginning of the process indicates that there is thus production of organic acids and thus substances containing simple sugars. The pH remained basic for all piles by ammonia gas production (Sánchez et al., 2017) associated with the degradation of aminereleasing proteins and the decomposition of organic acids (Sánchez et al., 2017) after the sixth week of production at the end of the process. This would also be related to the contamination of solid waste by wood ash and charcoal (Koledzi, 2011) because wood and charcoal are the energy sources for most households in the city of Sokodé.

The decrease of organic matter during the process could be explained by a degradation of organic matter by microorganisms. These grades indicate that 
the organic matter is stabilized and the composts have reached maturity. The organic matter content at the end of the process (mature compost) is greater than $35 \%$ for standard compost and more than $40 \%$ for enriched compost (Koledzi, 2011). Organic matter levels are higher than those found by Koledzi et al. (2011) in maturing composts.

The ratio $\mathrm{C} / \mathrm{N}$ decreases during composting (Table 3); this can be explained by the fact that the microorganisms consume more carbon than nitrogen (Sánchez et al., 2015). The carbon consumed is metabolized and released as carbon dioxid $\left(\mathrm{CO}_{2}\right)$ while the nitrogen is metabolized and released as volatile compounds such as $\mathrm{NH}_{3}$ (Sánchez et al., 2015).

\section{Compost quality \\ Content of nutrients}

The organic matter contents in both types of compos are comply with standards NFU 44-051 and NFU 44-095 and incate that the composts obtained are mature and stabilized for use as soil amendment (Rafolisy et al., 2015). The content of organic matter in co-compost is greater than the content in standard compost, confirming that sludge is richer in organic matter than the fermentable fraction of solid waste.

Concerning nitrogenous matter content, at the end of process, the values are in accordance with compost quality standards, although co-compost is richer in nitrogen than standard compost so its contribution to the improvement of the yield in agriculture will be higher. The low values of total nitrogen, NTK correlate with $\mathrm{pH}$ values (8-8.3).

The $\mathrm{C} / \mathrm{N}$ ratios presented are average but close to the value recommended by the standard NFU 44 - 051 which is 13 for mature compost. The $\mathrm{C} / \mathrm{N}$ ratios of the two types of compost are comparable, so it can be concluded that co-composting has made it possible to improve the $\mathrm{C} / \mathrm{N}$ ratio. Ammonia nitrogen and readily mineralizable organic nitrogen from sludge and fermentable fractions of solid waste in compost will be readily available to plants. The $\mathrm{C} / \mathrm{N}$ ratios is less than 20 indicating that composts will be able to mineralize rapidly and release significant amounts of nitrogen to crops (Bipfubusa et al., 2006).

Concerning the total phosphorus, the difference between co-compost and standard compost would be related to the nature of the substrates, the fecal sludge being richer in phosphorus than the solid waste. Indeed, foods especially cheese, livers, nuts, fish, meats, poultry, eggs particularly rich in phosphorus are generally consumed by the populations and can be found in high quantities in sludge more than garbage. These rates are high and will ensure the proper development of plant roots (Ouedraogo, 2016). The content of potassium in both types of composts is also in line with the standards NFU 44-051 and NFU 44-095. These contents could help to promote flowering and fruit development (Ouedraogo, 2016).

Finally, both types of compounds also have a high content of other nutrients wich are comparable to those obtained by ADEME (2007). These contents could be an advantage for using these composts in agriculture.

According to discussed results and comparing the contents of the two compost, has been possible conclude that the compost obtained from the fermentable fractions of solid waste and sludge in the proportions of $2 / 3$ and $1 / 3$ (respectively) has a higer potential for amendment (MO> 40\%) and fertilizer $(\mathrm{N}$ $+\mathrm{P}_{2} \mathrm{O}_{5}+\mathrm{K}_{2} \mathrm{O} \approx 5 \%$ ) than only FFOM.

\section{Maturity and stability of the compost}

The results of phytotoxicity shows that both composts produced are already highly stabilized (Koledzi, 2011). The values of Germinating index prove that the composts produced are not toxic for cowpea (Koledzi et al., 2019) and they are also stable and ripe (Koledzi et al., 2011). Finally, higher cation exchange capacity value obtained for both comports is characteristic of mature compost (Bernal et al., 1998); in any case, co-compost produces has shown a sligth higher value, so it is a bit more stable than standard one.

\section{Metallic trace element content}

The contents metallic trace element are below the threshold allowed to be applicable in agriculture. The use of these composts as organic fertilizers is therefore not an environmental problem. 


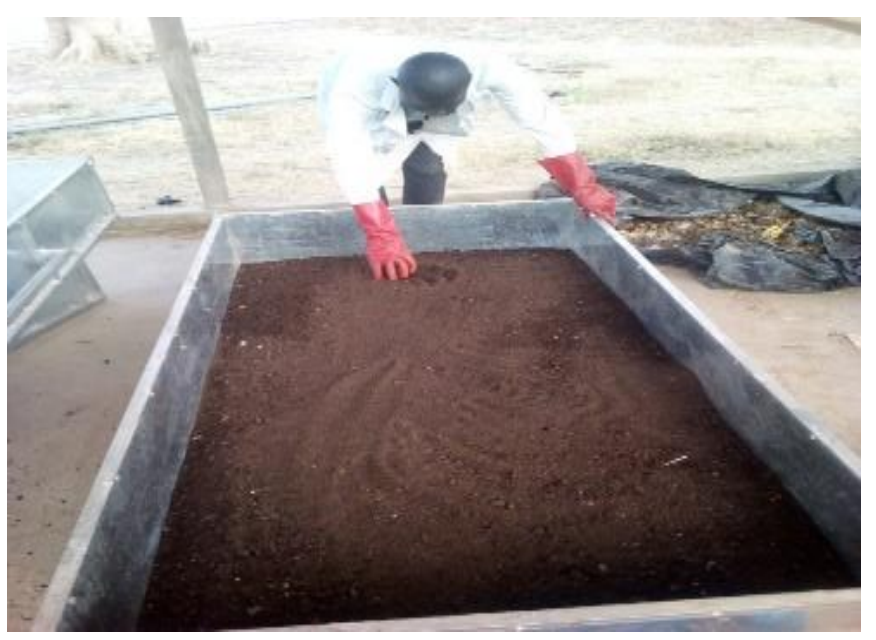

Photo 2: Co-compost.

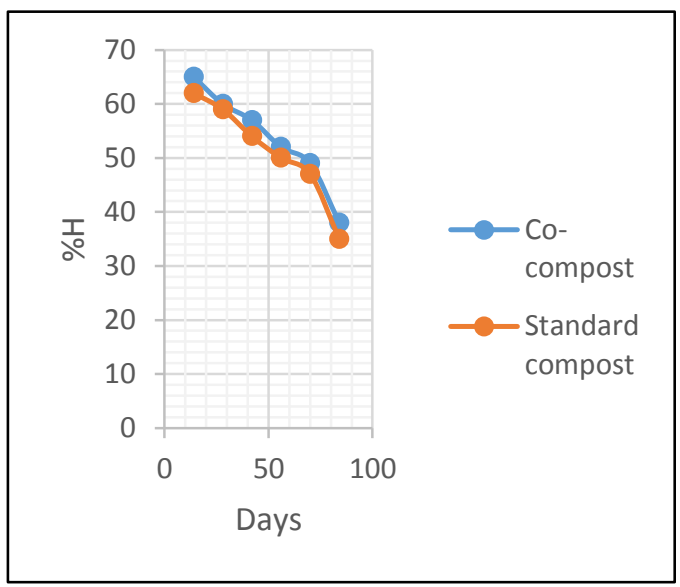

Figure 1: Variation of humidity.

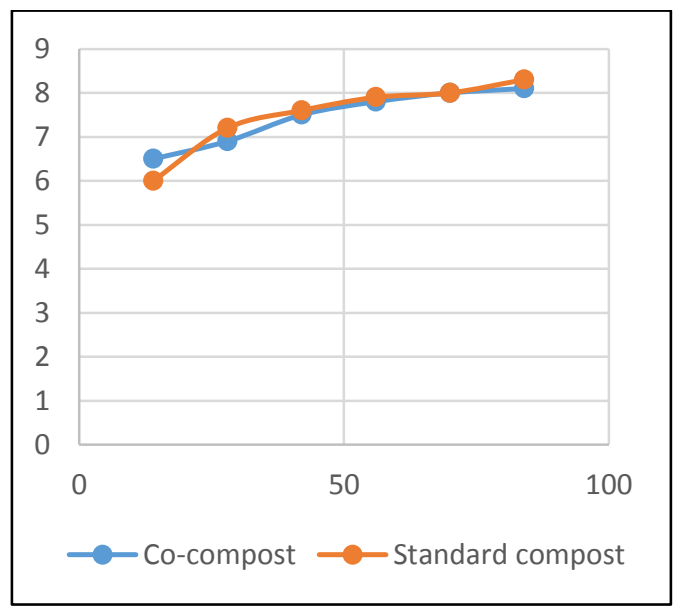

Figure 3: Variation of Hydrogen potential.

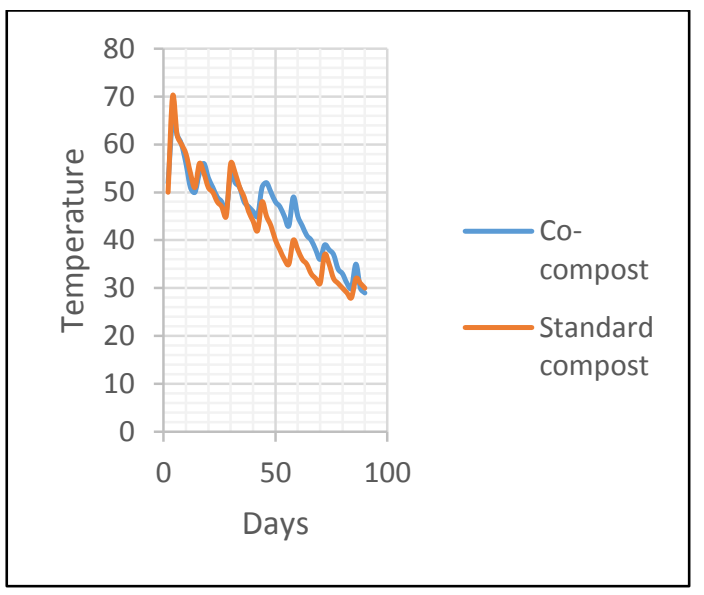

Figure 2: Variation of temperature.

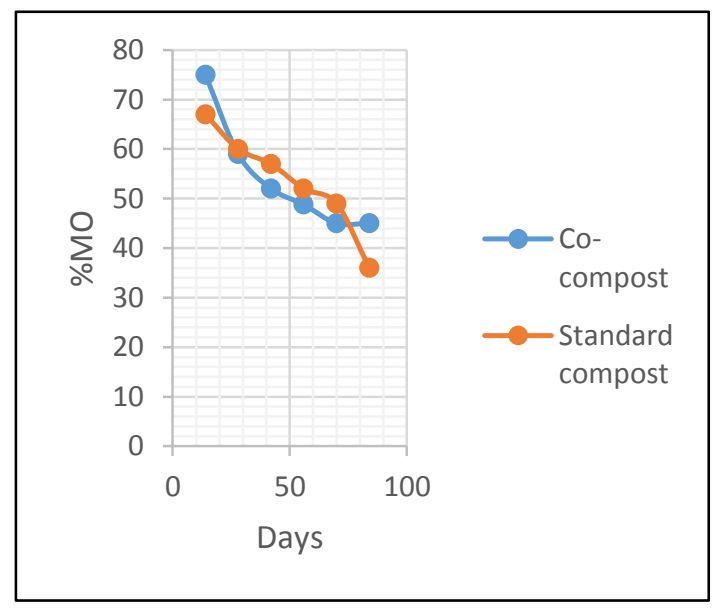

Figure 4: Variation of organic matter. 


\section{Conclusion}

At the end of this study, it should be said that the prior characterization of the dried sludge and the FFOM has shown that thes substrates are rich in organic matter, in nutriments such as nitrogen, phosphorus, potassium and magnesium. The analyzes on the dried sludge show an organic matter in advanced state of decomposition compared to that of the fermentable fractions of the solid waste and whose nutritive elements would be more or less easily available for the plants. The agronomic characteristics of these substrates lead to the conclusion that they can be used as a soil amendment. But drying alone is insufficient to destroy all pathogens and that the organic matte ris not stabilized in the two substrates, it was necessary to compost them. In this research two composts were produced; the first one only using fermentescible fraction of household waste and the second one mixing fermentescible fraction of household waste and dried sludge in a ratio $2 / 3$ of fermentescible fraction of household waste (FFOM) and 1/3 of dried sludge. The physico-chemical analyzes on the composts carried out to follow the co-composting and standard composting process have resulted on differences in the degradation process during co-composting and composting, showing a greater and faster degradation of organic matter during co-composting compared to the standard composting process. Humidity content, organique mater content and $\mathrm{C} / \mathrm{N}$ ration decreased during the composting process. The $\mathrm{pH}$ values at the end of the process, in composts are basic (8-9), due to the presence of ash in the waste. The organic matter contents at the end of ripening in both of compost are in accordance with standard NFU44-051. The maximum temperature reached in the fermentation phase in the cocompost pile and in standard compost pile is sufficient to destroy certain pathogens and reduce the risk of contamination of plant products. Thus, co-composting has made it possible to increase the temperature which can destroy certain pathogenic germs, unlike the composting of sludge only, during which the temperatures obtained are insufficient to destroy the pathogenic germs.Nutrient content, phytotoxicity, AT4 and CEC) on the composts were carried out and allowed to obtain the indicators that define the quality, maturity and stability of two types of compost produced. The $\mathrm{C} / \mathrm{N}$ ratios at the end of the process are average but close to the value recommended by the standard NFU $44-051$. The comparative study of the two types of compost showed that the compost obtained from the fermentable fractions of solid waste and sludge in the proportions has the highest potential for amendment (MO> 40\%) and fertilizer $\left(\mathrm{N}+\mathrm{P}_{2} \mathrm{O}_{5}+\mathrm{K}_{2} \mathrm{O} \approx 5 \%\right)$. The AT4 test gives a practically constant consumption for the fourth day (for a degree of maturation of IV (temperature $<40{ }^{\circ} \mathrm{C}$ )) for the two composts. The germination index is greater than $50 \%$. The values of these parameters show that the composts are ripe. The contents metallic trace element are lower than the standard NFU 44-051, so the use of these composts will not cause a problem for the environment. This research has concluded that co-composting dried sludge and fermentable fractions of solid waste in the city of Sokodé attests consequently that both organic fraction results on a substrate that could be used in agriculture. In consequence these fractions should be considered as resources that can contribute to improving the living conditions of the population by increasing agricultural production.

\section{COMPETING INTERESTS}

The authors declare that they have no competing interests.

\section{AUTHORS' CONTRIBUTIONS}

NMK was the principal investigator of the study. GB was the supervisor of the work. JM-P provided technical assistance and advice in the laboratory analyses and contributed to the writing of the paper. MZT contributed to the analyses, which were carried out in her laboratory, and to the writing of the paper. 


\section{ACKNOWLEDGMENTS}

I would like to thank European Union (UE) for the generous mobility that I grant by the ERASMUS + program.

Analyses were carried out in the Laboratory of Civil Engineering, Department of Chemical Engineering, University of Granada (Spain). I would like to underline the warm welcome I received during these three months of my stay, the quality of the support I received, the kindness and the availability that Professor Montserrat ZAMORANO TORO and Doctor Jaime MARTÍN-PASCUAL and their staff have shown me. I am really grateful.

\section{REFERENCES}

ADEME. 2015. Composting. Technical sheet. France. 20P.

ADEME. 2007. Audit of composting platforms for organic waste in France with compost analyzes, runoff water and balance of ADEME aid for composting green waste. ADEME market $\mathrm{n}^{\circ}$ $0306 \mathrm{C} 0057$.

AFNOR. 2005. Standard quality compost NF 44051, Organic amendment. Ministerial Order of August 21, 2007.

Barrena R, Turet J, Busquets A, Farrés M, Xavier F, Sánchez A. 2010. Respirometric. Screening of several types of manure and mixtures intended for composting. Bioresource Technology, 102(2): 1367-1377. DOI: 10.1016/j.biortech.2010.06.011.

Belyaeva, O.N., Haynes, R., 2009. Chemical, microbial and physical properties of manufactured soils produced by cocomposting municipal green waste with coal fly ash. Bioresource Technology, 100(21): 5203-5209. DOI: 10.1016/j.biortech.2009.05.032.

Bipfubusa M, N'Dayegamiye A, Tarradellas J. 2004. Quantification of sludge, example of the city of Ouahigouya, Burkina Fasso. EAWAG/SANDEC, Lausanne.8.P.

Bjorklund A. 2002. Speciation in birds. $J$. Evol. Biol., 15: 1095-1096. DOI: 10.1046/j.1420-9101.2002.00453x.
Bustamante, MA, Paredes, C., MarhuendaEgea, FC, Perez-Espinosa, A., Bernal, Moral MP, R., 2008. Co-composting of distillery wastes with animal manures: Carbon and nitrogen transformations in the evaluation of compost stability. Chemosphere, 72: 551-557. DOI: 10.1016/j.chemosphere.2008.03.030.

Carlton EJ, Liang S, Dowell JZ, Luo W, Remais JV. 2012. Regional disparities in the burden of disease attributable to unsafe water and poor sanitation in China. Bull World Health Organ, 90(8): 578-87. DOI: 10.2471/BLT.11.098343.

Douanla MP, Soh KE, Djumyom WGV, Letah NWA, Nounja ZM, Liegui GS, Wanda C, Fotso, Kengne. 2019. Quantification and characterization of faecal sludge from a tropical urban area: the case study of Douala, Cameroon. Int. J. Biol. Chem. Sci., 13(5): 105-113. DOI: https://dx.doi.org/10.4314/ijbcs.v13i5.8S

Food and Agriculture Organization of the United Nations (FAO). 2017. The future of food and agriculture - Trends and challenges. Rome. P.180.

Gallizzi K. 2003. Co-composting reduces helminth eggs in fecal sludge. SANDEC, Switzerland, a field study in Kumasi, Ghana.P.46.

Kolédzi KE. 2011. Valorization of urban solid waste in the neighborhoods of Lomé (Togo): Methodological approach for a sustainable production of compost. $\mathrm{PhD}$ thesis. University of Lomé.P.224.

Koledzi KE, Baba G, Segbeaya N, Tchangbedji G, Kili K, Tozo K, Gnandi K, Amouzouvi AA, Feuillade G, Matejka G. 2011.Valorisation of urban waste in agriculture: ecological impact Study of compost. J. Soc. Ouest-Afr. Chim., 32: 27-42. DOI: http://www.soachim.org.

Koledzi KE, Aziablé E, Megnassan S. 2019. Comparative study of the evolution of mass balance on the ENPRO composting platform in Togo. Journal of Chemical, Biological and Physical Sciences. DOI: 10.24214/jcbps.D.9.1.12737. 
Letah NWA, Soh SE, Djumyom WGV, Wanda C, Rechenburg A, Kengne NIM. 2019. Assessment of the faecal sludge management practices in households of a subSaharan Africa urban area and the health risks associated: the case study of Yaoundé, Cameroon. Int. J. Biol. Chem. Sci., 13(5): 1-23. DOI: https://dx.doi.org/10.4314/ijbcs.v13i5.1S

Miyuki C, Ryuzoh I, Kagan K, Yasutaka M, Eiichi T. 2005. Estimation of maturity of compost from food wastes and agroresidues by multiple regression analysis. Bioresource Technology, 97: 1979-1985. DOI: 10.1016/j.biortech.2005.09.026.

Ouedraogo OB. 2016. Characterization of dried sludge and treated percolate of the Zagtouli treatment plant for agronomic development. Master Memory. P.89.

Oviedo OER, Torres-Lozada P, MarmolejoRebellon LF, Hayos LV, Gonzales S, Barrena R, Komilis D, Sanchez A. 2015. Stability and maturity of biowaste composts derived by small municipalities: Correlation among physical, chemical and biological indices. Waste Management, 44: 63-71. DOI :

https://doi.org/10.1016/j.wasman.2015.0 7.034 .

PEAT2. 2018. Quantification and characterization of the sludge deposit in the city of Sokodé. Specific production of sludge per capita. Raport.P.39.

Remy A. 2007. Co-composting sewage sludge and green waste sludge: New methodology for monitoring organic matter transformations. $\mathrm{PhD}$ Thesis, University Paul Cézanne. P.190.
Sánchez OJ, Ospina DA, Montoya S. 2017. Compost supplementation with nutrients and microorganisms in composting process. Waste Management, 69: 136153. DOI: https://doi.org/10.1016/j.wasman.2017.0 8.012 .

Savci. 2012. Investigation of Effect of Chemical Fertilizers on Environment. Chemical, Biological \& Environmental Engineering Society, 1: 287-292. DOI: https://doi.org/10.1016/j.apcbee.2012.03. 047.

Rafolisy T, Thuriès L, Técher P, Moussard G, Paillat JM.2015.Co-composting of beer sludge and cattle manure on Reunion Island: hygienisation, nutrient losses and homogeneity of compost produced. Bio. Technol. Agron. Soc. Environ., 19(4): 329-337.

Unmar G, Mohee R. 2008. Assessing the effect of biodegradable and degradable plastics on the composting of green wastes and compost quality. Bioresource Technology, 99: 6738-6744. DOI: 10.1016/j.biortech.2008.01.016.

Yobouet YA, Adouby K, Trokourey A, Yao B. 2010. Cadmium, Copper, Lead and Zinc speciation in contaminated soils. International Journal of Engineering Science and Technology, 2(5): 802-812. DOI:

https://www.researchgate.net/profile/Ad ouby_Kopoin/publication. 